\title{
K životnímu jubileu prof. MUDr. Lenky Špinarové, Ph.D., FESC
}

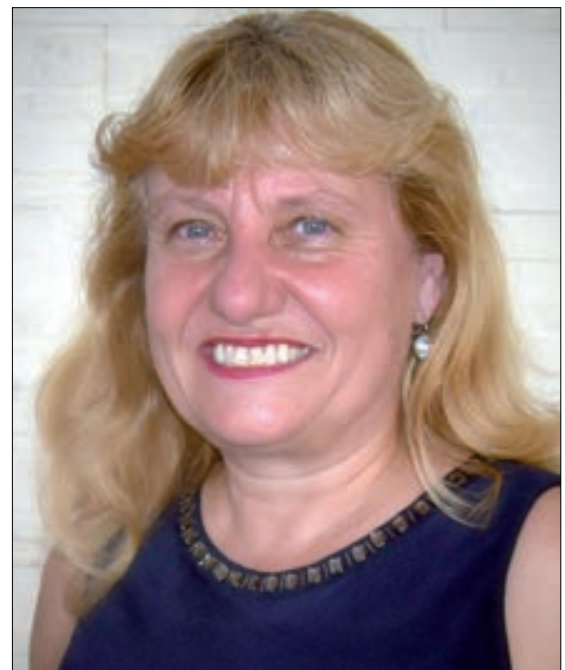

Obr. 1 - Prof. MUDr. Lenka Špinarová, Ph.D., FESC

Vážená paní profesorko, milá Lenko,

před deseti lety jsem začínal Tvé laudatio takto: „Je pro mne velkou ctí, že mohu psát tento oslavný článek $k$ Tvému neuvěřitelnému jubileu. Neuvěřitelnému proto, že věk, kterého se dožíváš, je kontradikcí ve dvou směrech. Fyzicky vypadáš nejméně o deset let mladší, zatímco odborně a publikačně jsi dosáhla toho, čeho běžný vědecký a vysokoškolský pracovník dosahuje minimálně o deset let později," a tak dále. Dnes po deseti letech $k$ tomu úvodu Ize jen dodat, že jsi dosáhla dalších významných úspěchů a vypadáš stále mladě. V roce 2013 jsem Ti předal vedení kliniky ve velmi obtížné situaci, přesun kliniky do nové budovy, spolupráce s novým vedením International Clinical Research Center (ICRC) a další obtížné úlohy, které jsi bravurně zvládla.

Nyní pro ty, kdo Tě méně znají po osobní stránce, připomenu pár faktů z Tvého životopisu.

Paní profesorka Lenka, tehdy jako Pličzková, se narodila 6. srpna 1961 v rodině dvou lékařů v Brně. Gymnázium studovala s vynikajícím prospěchem a při olympiádě z biologie se poprvé sešla, i když nakrátko, se svým budoucím manželem Jindřichem. $V$ roce 1979 nastoupila na lékařskou fakultu v Brně a zde se hned na počátku studia setkala podruhé s Jindřichem a jejich př́kladný a následování hodný vztah trvá stále. $V$ té době udivovala mnohé bezchybnou hrou mariáše a zápalem pro odbíjenou. Se svým budoucím manželem se už jako medici díky prof. Ivo Dvořákovi na II. interní klinice FN u sv. Anny začali věnovat kardiologii v rámci SVOČ a společně dosáhli významných výzkumných úspěchů nejen v rámci republiky, ale také mezinárodně. Rok 1984 byl jejich rokem svatebním. Lenka promovala $v$ roce 1985 s červeným diplomem a obdržela cenu rektora Univerzity Jana Evangelisty Pur- kyně (UJEP) za vynikající studijní i odborné výsledky. Po promoci nastoupila na interní oddělení nemocnice Ivančice. $V$ roce 1987 se narodila dcera Monika. Po mateřské dovolené dostala Lenka nabídku pracovat na I. interní klinice FN u sv. Anny, kterou v té době vedl doc. MUDr. Z. Lupínek a na této klinice je doposud. V roce 1989 složila úspěšně atestaci z vnitřního lékařství, v roce 1993 atestovala z kardiologie. Od roku 1994 do roku 2002 byla odbornou asistentkou Lékařské fakulty Masarykovy univerzity (LF MU) Brno. V roce 2000 dokončila postgraduální vědecké studium při LF MU Brno a získala titul Ph.D. (obr. 1). Její doktorandská práce byla oceněna Cenou rektora za nejlepši doktorandskou práci v rámci MU. Dva roky poté habilitovala a v roce 2005 byla jmenována prezidentem republiky profesorkou vnitřního lékařství na LF MU. $\checkmark$ letech 2002-2012 byla zástupkyní přednosty kliniky pro školství a od roku 2013 doposud je prednostkou I. interní kardioangiologické kliniky LF MU a FN u sv. Anny. V České kardiologické společnosti byla pokladníkem výboru, dále pracovala či pracuje ve výborech pracovních skupin ČKS: jako členka výboru Asociace srdečního selhání ČKS, jako místopředsedkyně Pracovní skupiny kardiovaskulární farmakoterapie ČKS. Dále je členkou České společnosti pro hypertenzi, České transplantační společnosti, České internistické společnosti ČLS JEP. Oceněním její odborné činnosti je jmenování Fellow of European Society of Cardiology - FESC a členství ve Working Group on Heart Failure of European Society of Cardiology (ESC), Working Group on Cardiac Rehabilitation of ESC, Working Group on Echocardiography of ESC. $V$ roce 2018 jí bylo uděleno prestižní ocenění Lady Pro od Comenius-Panevropské společnosti pro kulturu, vzdělávání a vědecko-technickou spolupráci a letos jí bylo uděleno čestné členství ČKS.

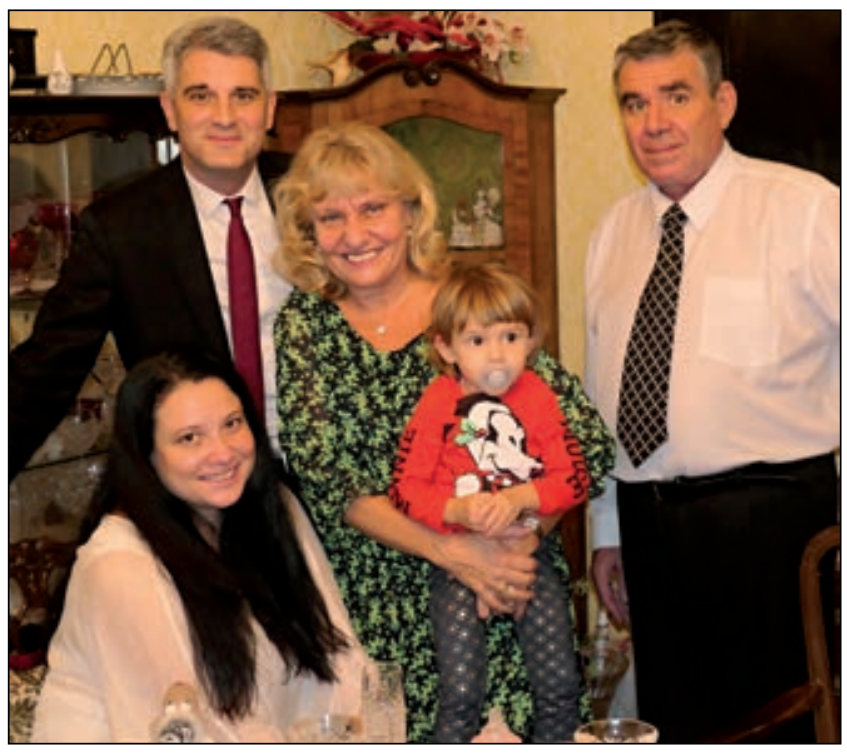

Obr. 2 - Profesorka Špinarová s rodinou 
Je předsedkyní Oborové rady pro kardiologii Ph.D. studia LF MU a členkou Aprobační komise LF MU pro habilitační a profesorská řízení, školitelkou Ph.D. studentů, členkou zkušební komise pro atestace z kardiologie a členkou Vědecké rady LF MU Brno.

Je úspěšnou řešitelkou sedmi grantů. Publikovala přes 330 článků v české odborné literatuře, 81 článků v zahraniční literature, prednesla více než 329 domácích a 183 zahraničních sdělení. Je autorkou či spoluautorkou více než 15 interních a kardiologických učebnic. Má nadprůměrnou citovanost: Web of Science: 2 955, Scopus: 5 870, Hirschův index 25. Věnuje se transplantačnímu programu spolu se srdečním selháním a také intenzivně echokardiografii.

Jako přednostka přední kardiologické kliniky nejen garantuje odbornou péči o nemocné s kardiologickými či interními diagnózami, zajištuju vysokou úroveň výuky mediků $L F$, aktivně podporuje vědeckou činnost členů kliniky, zajistila řadu odborných stáži mladších kolegů, což zvláště $v$ současné covidové době nebylo vždy snadné.

Milá paní profesorko Lenko, jako Tvưj zástupce pro výuku, co mám ještě dodat při ohlédnutí za Tvou úspěšnou kariérou jak medicínskou, pedagogickou i výzkumnou. Známe se již více než 30 let. Po nástupu na I. interní (nyní kardioangiologickou) kliniku ses pomalu začala věnovat problematice srdečního selhání pod vedením budoucího přednosty prof. Tomana a zde začala naše odborná spolupráce. $V$ té době začalo naše velmi úzké rodinné prátelství, které bylo a jest stále utvrzováno řadou našich společných dovolených a kongresových aktivit. Po mém nástupu na I. interní kardioangiologickou kliniku jsi mi nesmírně pomohla při nelehkých začátcích mého přednostování a jsem velmi rád, že jsi kliniku po mně povznesla ještě na vyšší úroveň.

Tak Ti přeji hodně všeho dobrého jak v práci, tak doma, abys byla nadále spokojená a měla velkou radost z vnučky Belinky, dcery Moničky, která je úspěšnou kardioložkou, zetě Petra a hlavně s Jindrou, který Ti také má za co být vděčný (obr. 2).

\section{AD MULTOS ANNOS ET AETATE FRUERE: MOBILI CURSU FUGIT,}

Tvůj školský zástupce a hlavně přitel Jiří

Prof. MUDr. Jiří Vítovec, CSc., FESC, I. interní kardioangiologická klinika, Lékařská fakulta Masarykovy univerzity a Fakultní nemocnice u sv. Anny v Brně 